\title{
PREVALENCE OF LATEX ALLERGY AMONG HEALTHCARE WORKERS IN IZMIR (TURKEY)
}

\author{
Şükran Köse ${ }^{1}$, Aliye Mandıracıoğlư ${ }^{2}$, Bengü Tatar ${ }^{1}$, Selma Gül'1, Mehmet Erdem ${ }^{1}$ \\ ${ }^{1}$ Allergy-Immunology Unit, Department of Infectious Diseases and Clinical Microbiology, Tepecik Education and Research Hospital, Izmir, Turkey \\ ${ }^{2}$ Department of Public Health, Medical Faculty, Ege University, Izmir, Turkey
}

\section{SUMMARY}

The purpose of this study was to determine prevalence of natural rubber latex (NRL) allergy among healthcare employees and identify sensitive individuals.

A total of 1,115 healthcare workers (HCWs) employed in Izmir Tepecik Education and Research Hospital participated in the study. Information on age, gender, occupation, history of allergy, and complaints were collected through a questionnaire. Serum latex-specific lgE level was determined. Among HCWs enrolled in the study, prevalence of latex sensitization was determined as $4.2 \%$. More frequent occurrence of latex allergy was detected among nurses. Family history of allergy and history of personal food allergy were significantly more often noted among individuals with latex allergy. Latex is considered to be the leading source of occupational health problems.

Key words: latex, allergy, healthcare workers

Address for correspondence: S. Köse, Izmir Tepecik Education and Research Hospital, Clinic of Infectious Diseases and Clinical Microbiology, Gaziler Street 468, Yenisehir, Konak, 35220 Izmir, Turkey. E-mail: b.gtatar@hotmail.com

\section{INTRODUCTION}

Natural rubber Latex (NRL) is a cytoplasmic excuda produced by complex proteins of rubber tree Hevea brasiliensis (1). Low cost, durability and elasticity of latex lead to indispensable use of this material in a number of products. Latex is used in medical objects such as gloves, condoms, balloons, and catheters.

Latex sensitivity is reported in $\leq 1 \%$ of non-atopic general population but reaches up to $5-15 \%$ among healthcare employees (2). This discrepancy in prevalence may be associated with different diagnostic procedures or it may be associated with the frequency of use and the quality of gloves $(3,4)$. Exposure to latex products may occur through contact with skin and mucosal surface or through respiratory tract (5-7). Eventually, powdered latex gloves spread latex antigens into the work environment (8). Powder is an allergen carrier. Sensitized persons may have asthmatic and systemic reactions to airborne NRL proteins associated with the use of powder (9). Latex allergy is a frequent occupational disease among healthcare personnel and the leading source of occupational allergies $(8,10,11)$.

It is reported that reactions to NRL gloves can present in three ways: first is contact dermatitis on the hands after wearing gloves resulting from mechanical friction and drying. Second is the type I immediate hypersensitivity reaction to latex, an IgE-mediated hypersensitivity reaction to latex protein, and third is allergic contact dermatitis which is a type IV delayed hypersensitivity reaction usually caused by the chemical accelerators. This is a cell-mediated immune response that develops 24-48 hours after exposure to latex (12). A type IV reaction may be an increasing problem with stricter hospital hand-cleaning policies $(13,14)$.

Nonimmunological irritant contact dermatitis is manifested as irritative eczema with redness, scaling and itching. A delayed-type allergic is contact eczema caused by glove contact. Immediatetype reaction to NRL is IgE-mediated, and the term latex allergy is usually used to describe this. Progressive sensitization can also lead to generalized urticaria, angioedema, rhinitis, conjunctivitis, asthma, and anaphylactic shock (9). Incidence of latex allergy may be reduced through certain precautions implemented in health institutions. Abandoning unnecessary use of gloves, use of nonpowdered gloves by all healthcare employees and use of non-latex gloves for sensitive individuals are the main precautions (10, 13). In the study conducted by Kelly et al., use of non-powdered gloves by all health personnel resulted in 16 -fold decrease of latex sensitivity (15). It is important to increase awareness of the sensitising and disease-causing effect of latex gloves in HCWs (16).

The staff who test positive for latex allergy should know what items to avoid, should be aware of alternatives to products containing latex, and should know how to manage allergic reactions. The variety of physical properties of different glove materials allows individuals to select the appropriate gloves for a given situation. For example, waste handlers can wear thicker vinyl gloves, and housekeeping personnel can wear reusable gloves that can be washed and dried (17).

The aim of the current study was to determine the prevalence of latex allergy among HCWs and to identify sensitive individuals.

\section{MATERIAL AND METHODS}

\section{Study Design}

This cross-sectional study among HCWs (physicians, nurses, midwives, medical assistants, and other) was carried out in Izmir, Turkey. Out of 1,860 personnel employed in Izmir Tepecik Educa- 
tion and Research Hospital 1,115 (59.4\%) persons participated voluntarily in this study. The self-administered questionnaire was filled to collect the demographic data, work-related data and known food-drug allergy, smoking habit, family and personal history of allergy, and clinical complaints and symptoms observed following use of latex products. Verbal informed consent was obtained from the participants.

\section{Allergy Testing Procedure}

Latex specific IgE was measured in serum (Alisei quality system, RADIM, Italy). Test was performed as per manufacturer's recommendations: $<0.36 \mathrm{KIU} / \mathrm{L} 0$ was evaluated as negative.

\section{Data Analysis}

All data analysis was performed using SPSS ver. 13.0 software package. Chi-square analysis was performed for comparison between latex specific IgE negative and positive groups. P values below 0.05 were regarded as significant.

\section{RESULTS}

Out of 1,115 participating HCWs, 597 were women (53.5\%) and 518 were men $(46.7 \%)$. Mean age was determined as $33.6 \pm 6$ years. As per occupations, there were 292 nurses, 223 physicians, 192 laboratory staff, 172 secretaries and 236 housekeeping staff (Table 1).

The prevalence of NRL hypersensitivity was found to be $4.2 \%$. Mean age of cases diagnosed as latex specific IgE positive was $31.5 \pm 5.7$ years; 31 were women $(66 \%)$ and 16 were men $(34 \%)$. Latex sensitivity rate was $43 \%$ among atopic individuals. Upon evaluation of gender, division of employment, history of drug allergy, smoking and pet owners, occupational groups, no statistically significant difference was found between latex specific IgE positive and negative groups ( $\mathrm{p}>0.05)$. Family history of allergy (OR: $3.32 ; 1.74-6.31)$ and food allergy history $(2.26 ; 1.08-4.44)$ were risk factor for latex allergy. $47 \mathrm{HCWs}$ with latex specific IgE positivity had some allergic symptoms after contact with latex containing products, e.g. protein contact dermatitis was found in $61.7 \%$, allergic rhinitis in $27.7 \%$, allergic conjunctivitis in $6.4 \%$, and asthma in $4.2 \%$ of HCWs (Table 2).

\section{DISCUSSION}

HCWs, particularly nurses, physicians and laboratory staff, constitute the occupational group at highest risk in terms of development of latex allergy. Various rates of prevalence were reported in studies conducted on NRL hypersensitivity. Şener et al. determined $9.22 \%$ rate of prevalence for latex sensitivity among $206 \mathrm{HCWs}$ who regularly used latex gloves (18). Eseverri et al. assessed the prevalence of latex allergy by skin tests with a rate of $1.08 \%$ while the rate in subjects with latex specific IgE was determined in $7.2 \%$ of examined (19). The rate in our study was $4.2 \%$. In a previous trial conducted in Izmir among 120 healthcare workers, positivity was found by skin test in 25 individuals (20). The prevalence of latex allergy found out in the study conducted
Table 1. Characteristics of participants

\begin{tabular}{|c|c|c|c|c|}
\hline & \multicolumn{2}{|c|}{$\begin{array}{c}\text { Latex specific lgE } \\
\text { positive (N=47) }\end{array}$} & \multicolumn{2}{c|}{$\begin{array}{c}\text { Total study group } \\
(\mathrm{N}=1,115)\end{array}$} \\
\cline { 2 - 5 } & $\mathrm{n}$ & $\%$ & $\mathrm{n}$ & $\%$ \\
\hline
\end{tabular}

\begin{tabular}{|l|c|c|c|c|}
\hline Gender \\
\hline Male & 16 & 34.0 & 518 & 46.5 \\
\hline Female & 31 & 66.0 & 597 & 53.5 \\
\hline Occupation & \multicolumn{5}{|l|}{} \\
\hline Physician & 10 & 21.3 & 223 & 20.0 \\
\hline Nurse & 18 & 38.3 & 292 & 26.2 \\
\hline Laboratory staff & 8 & 17.0 & 192 & 17.2 \\
\hline Housekeeping staff & 11 & 23.4 & 236 & 21.2 \\
\hline Secretary & 0 & 0 & 172 & 15.4 \\
\hline Division & & & & \\
\end{tabular}

\section{Division}

\begin{tabular}{|l|l|l|l|l|}
\hline Internal & 26 & 35.3 & 678 & 60.8 \\
\hline Surgical & 21 & 44.7 & 437 & 39.2 \\
\hline
\end{tabular}

Food allergy

\begin{tabular}{|l|c|c|c|c|}
\hline Yes & 6 & 12.8 & 118 & 10.6 \\
\hline No & 41 & 87.2 & 997 & 89.4 \\
\hline
\end{tabular}

Drug allergy

\begin{tabular}{|l|c|c|c|c|}
\hline Yes & 4 & 8.5 & 44 & 3.9 \\
\hline No & 43 & 91.5 & 1,071 & 96.1 \\
\hline
\end{tabular}

Family history of allergy

\begin{tabular}{|l|c|c|c|c|}
\hline Yes & 11 & 23.4 & 97 & 8.7 \\
\hline No & 36 & 76.6 & 1,018 & 91.3 \\
\hline
\end{tabular}

Smoking

\begin{tabular}{|l|c|c|c|c|}
\hline Yes & 7 & 14.9 & 136 & 12.2 \\
\hline No & 40 & 5.1 & 979 & 87.8 \\
\hline
\end{tabular}

Pet owners

\begin{tabular}{|l|c|c|c|c|}
\hline Yes & 1 & 2.1 & 29 & 2.6 \\
\hline No & 46 & 97.9 & 1,086 & 97.4 \\
\hline
\end{tabular}

Table 2. Clinical symptoms of individuals with latex sensitization $(N=47)$

\begin{tabular}{|l|c|c|}
\hline Symptoms & $\mathbf{n}$ & $\%$ \\
\hline Contact dermatitis & 29 & 61.7 \\
\hline Allergic rhinitis & 13 & 27.7 \\
\hline Allergic conjunctivitis & 3 & 6.4 \\
\hline Asthma & 2 & 4.2 \\
\hline History of anaphylaxis & 0 & 0.0 \\
\hline
\end{tabular}

on primary care providers was $5.9 \%$. In a South African study, $11.9 \%$ of HCWSs were allergic to latex (14).

In the current study, contact dermatitis was determined in $61.7 \%$, rhinitis in $27.7 \%$, allergic conjunctivitis in $6.4 \%$, and asthma in $4.2 \%$ of examined subjects. Turjanmaa et al. conducted a study on 160 cases with latex allergy and determined as the most common allergic reaction contact urticaria (64\%), followed by eczema (37\%) and eye symptoms (23\%), respectively (22). Verna 
et al. determined the most common condition as eczema (23). In a study performed by Buss and Fröde, a 6.8-fold increase in allergic symptoms was reported among cases with latex allergy (8). In the South African study, the symptoms experienced were rhinitis in $12(100.0 \%)$, asthma in $6(50.0 \%)$, dermatitis in $3(25.0 \%)$, and urticaria in $1(8.3 \%)$ of the examined subjects (14).

We determined that latex allergy was more common among nurses. Similarly, Amarasekera et al. reported a higher rate of latex allergy among nurses (24). In a study conducted in Bolu - Turkey, significantly higher rate of latex allergy was also determined among nurses (25). No difference was found in terms of field of employment. Similar results were obtained in several studies (26). On the other hand, several studies report a higher rate of latex allergy among surgical department staff $(23,27)$. This finding was associated with presence of a higher rate of airborne latex particles in surgical departments (28).

Even though there is no distinct data in literature on this topic, female gender was reported as a risk factor for latex allergy in several trials (29). In the current study, $66.0 \%$ of cases diagnosed with latex allergy were women.

In recent years, it has been well established that prevalence of latex sensitivity is increasing among healthcare workers, primarily among atopic individuals. Most probably, atopy is the most significant predisposing factor for latex sensitization (30). In our study, corresponding rate was determined at $43 \%$. Latex allergy was determined to be more common among persons with food allergy. In this study, rate of allergy for at least one type of food was determined in $12.8 \%$ of the latex sensitive group while the corresponding rate in the group with no latex sensitivity was determined at $10.6 \%$. In individuals with latex allergy, sensitization was determined for tropic fruits like banana, avocado and kiwi, and this was suggested to be due to allergens causing crossreactions $(31,32)$.

There were some limitations of the study. The data related risk factors depends on the study subjects' expressions. Results of this study are not generalizable to all Turkish healthcare personnel. But this hospital is a big tertiary care center and serves the whole Aegean area.

Latex allergy is rather an occupational disease of healthcare workers. Medical treatment may reduce allergic symptoms but the most effective is termination of exposure. Non-powdered gloves containing reduced amount of protein or, if available, neolon products should be used instead of latex products. Sasaki and Kanda found that the use of latex gloves was a significant risk factor for occupational dermatitis and they reported that some occupational dermatitis may be preventable by managing appropriate glove selection (33). Allmers et al. reported that education about NRL allergies in healthcare facilities combined with the introduction of powder-free gloves with reduced protein levels has been associated with a decline of the occupational allergies caused by NRL in Germany (34). Our results indicate a significant occupational health problem among healthcare personnel wearing latex gloves. Healthcare workers with history of allergy in particular, represent an occupational group carrying the highest risk of developing latex allergy. Therefore, risk groups should be informed and non-powdered gloves with reduced protein or neolon materials, if available, should be used instead of latex products.

\section{REFERENCES}

1. Sussman GL, Beezhold DH, Liss G. Latex allergy: historical perspective. Methods. 2002 May;27(1):3-9.

2. Lagier F, Vervloet D, Lhermet I, Poyen D, Charpin D. Prevalence of latex allergy in operating room nurses. J Allergy Clin Immunol. $1992 \mathrm{Sep} ; 90$ (3 Pt 1):319-22.

3. Galindo MJ, Quirce S, Garcia OL. Latex allergy in primary care providers. J Investig Allergol Clin Immunol. 2011;21(6):459-65.

4. Kujala V. A review of current literature on epidemiology of immediate glove irritation and latex allergy. Occup Med (Lond). 1999 Jan;49(1):3-9.

5. Beuers U, Baur X, Schraudolph M, Richter WO. Anaphylactic shock after game of squash in atopic woman with latex allergy. Lancet. 1990 May 5;335(8697):1095.

6. Spaner D, Dolovich J, Tarlo S, Sussman G, Buttoo K. Hypersensitivity to natural latex. J Allergy Clin Immunol. 1989 Jun;83(6):1135-7.

7. SGNA Guidelines: Guidelines for preventing sensitivity and allergic reactions to natural rubber latex in the workplace. Gastroenterol Nurs. 2004 Jul-Aug;27(4):191-6.

8. Buss ZS, Fröde TS. Latex allergen sensitization and risk factors due to glove use by health care workers at public health units in Florianopolis, Brazil. J Investig Allergol Clin Immunol. 2007;17(1):27-33.

9. Brehler R, Kütting B. Natural rubber latex allergy: a problem of interdisciplinary concern in medicine. Arch Intern Med. 2001 Apr 23;161(8):105764.

10. Filon FL, Radman G. Latex allergy: a follow up study of 1040 healthcare workers. Occup Environ Med. 2006 Feb;63(2):121-5.

11. Cabañes N, Igea JM, de la Hoz B, Agustín P, Blanco C, Domínguez J, et al.; Committee of Latex Allergy; SEAIC. Latex allergy: Position Paper. J Investig Allergol Clin Immunol. 2012;22(5):313-30; quiz follow 330.

12. Lopes RA, Benatti MC, Zollner RL. Occupational exposure of Brazilian neonatal intensive care workers to latex antigens. Allergy. 2004 Jan;59(1):107-10.

13. Palosuo T, Antoniadou I, Gottrup F, Phillips P. Latex medical gloves: time for a reappraisal. Int Arch Allergy Immunol. 2011;156(3):234-46.

14. Risenga SM, Shivambu GP, Rakgole MP, Makwela ML, Nthuli S, Malatji TA, et al. Latex allergy and its clinical features among healthcare workers at Mankweng Hospital, Limpopo Province, South Africa. S Afr Med J. 2013 Mar 15;103(6):390-4.

15. Kelly KJ, Wang ML, Klancnik M, Petsonk EL. Prevention of IgE Sensitization to Latex in Health Care Workers After Reduction of Antigen Exposures. J Occup Environ Med. 2011 Aug;53(8):934-40.

16. Al-Niaimi F, Chiang YZ, Chiang YN, Williams J. Latex allergy: assessment of knowledge, appropriate use of gloves and prevention practice among hospital healthcare workers. Clin Exp Dermatol. 2013 Jan;38(1):77-80.

17. Kumar RP. Latex allergy in clinical practice. Indian J Dermatol. 2012 Jan;57(1):66-70.

18. Sener O, Taskapan O, Ozangüç N. Latex allergy among operating room personnel in Turkey. J Investig Allergol Clin Immunol. 2000 JanFeb;10(1):30-5.

19. Eseverri JL, Botey J, Cozzo M, Pena M, Marín AM. Prevalence of allergy to latex in the pediatric population. Allergol Immunopathol (Madr). 1999 May-Jun;27(3):133-40.

20. Kose S, MandIracIgĝu A. Latex allergy in Bozyaka Social Security Hospital workers, Turkey. Chin Med J (Engl). 2004 Feb;117(2):305-7.

21. Galindo MJ, Quirce S, Garcia OL. Latex allergy in primary care providers. J Investig Allergol Clin Immunol. 2011;21(6):459-65.

22. Turjanmaa K, Kanto M, Kautiainen H, Reunala T, Palosuo T. Long-term outcome of 160 adult patients with natural rubber latex allergy. J Allergy Clin Immunol. 2002 Aug;110(2 Suppl):S70-4.

23. Verna N, Di Giampaolo L, Renzetti A, Balatsinou L, Di Stefano F, Di Gioacchino G, et al. Prevalence and risk factors for latex-related diseases among healthcare workers in an Italian general hospital. Ann Clin Lab Sci. 2003 Spring;33(2):184-91.

24. Amarasekera M, Rathnamalala N, Samaraweera S, Jinadasa M. Prevalence of latex allergy among healthcare workers. Int J Occup Med Environ Health. 2010;23(4):391-6.

25. Ozkan O, Gökdogan F. The prevalence of latex allergy among health care workers in Bolu (Turkey). Dermatol Nurs. 2003 Dec;15(6):543-7.

26. Koh D, Ng V, Leow YH, Goh CL. A study of natural rubber latex allergens in gloves used by healthcare workers in Singapore. Br J Dermatol. 2005 Nov;153(5):954-9.

27. Nettis E, Assennato G, Ferrannini A, Tursi A. Type I allergy to natural rubber latex and type IV allergy to rubber chemicals in health care workers 
with glove-related skin symptoms. Clin Exp Allergy. 2002 Mar;32(3):4417.

28. Diéguez MC, Pulido Z, de la Hoz B, Blanco R, Cerecedo I, Fernández-Caldas E, et al. Latex allergy in healthcare workers: an epidemiological study in a Spanish hospital. Allergy Asthma Proc. 2007 Sep-Oct;28(5):564-70.

29. Pecquet $C$, Leynadier F. IgE mediated allergy to natural rubber latex in 100 patients. Clin Rev Allergy. 1993 Fall;11(3):381-4.

30. Khader Y, Abu-Zaghlan M, Abu-Al Rish I, Burgan S, Amarin Z. Selfreported allergy to latex gloves among health care workers in Jordan. Contact Dermatitis. 2005 Dec;53(6):339-43.

31. Brehler R, Theissen U, Mohr C, Luger T. "Latex-fruit syndrome": frequency of cross-reacting IgE antibodies. Allergy. 1997 Apr;52(4):404-10.
32. Freeman GL. Cooccurrence of latex and fruit allergies. Allergy Asthma Proc. 1997 Mar-Apr;18(2):85-8

33. Sasaki M, Kanda K. Glove selection as personal protective equipment and occupational dermatitis among Japanese midwives. J Occup Health. 2006 Jan;48(1):35-43.

34. Allmers H, Schmengler J, Skudlik C. Primary prevention of natural rubber latex allergy in the German health care system through education and intervention. J Allergy Clin Immunol. 2002 Aug;110(2):318-23.

Received April 8, 2013 Accepted in revised form March 14, 2014 